\title{
Antagonismo microbiano en la terapia de las enfermedades infecciosas
}

\author{
Walter Ledermann
}

Hospital Luis Calvo Mackenna.

Recibido: 13 de junio de 2013

Correspondencia a: Walter Ledermann Dehnhardt oncemayor@gmail.com

\section{Microbial antagonism in the therapy of infectious diseases}

The history of antibiotics begins with the first observations of Pasteur and Joubert about microbial antagonism at the end of the XIX century. Three types of antagonism were studied: bacterial killing by other bacteria, virus against bacteria and blockade of cellular receptors by bacterial filtrates. In the first type, the piocianase from Pseudomonas aeruginosa and the activity of Bacillus subtilis over Mycobacterium tuberculosis were the better examples; in the second, the French D'Herelle was a pioneer using bacteriophages against Shigella dysenteriae; and another French, Besredka, headed the third line with his "antivirus thérapie" on Staphylococcus aureus.

Key words: Microbial antagonism, bacteriophages, D’Herelle, Besredka.

Palabras clave: Antagonismo microbiano, bacteriófagos, D’Herelle, Besredka.

\section{Prefacio profético}

$\mathrm{E}$ n su célebre carta a los historiadores el Papa Celestino VI, feliz creación literaria de Giovanni Papini, nos fustiga diciéndonos: Deberiais ser profetas del pasado, y sois, en cambio, cicerones de cementerio... coleccionistas de lápidas funerarias, archivadores de epitafios, redactores de etiquetas, computadores de cro-

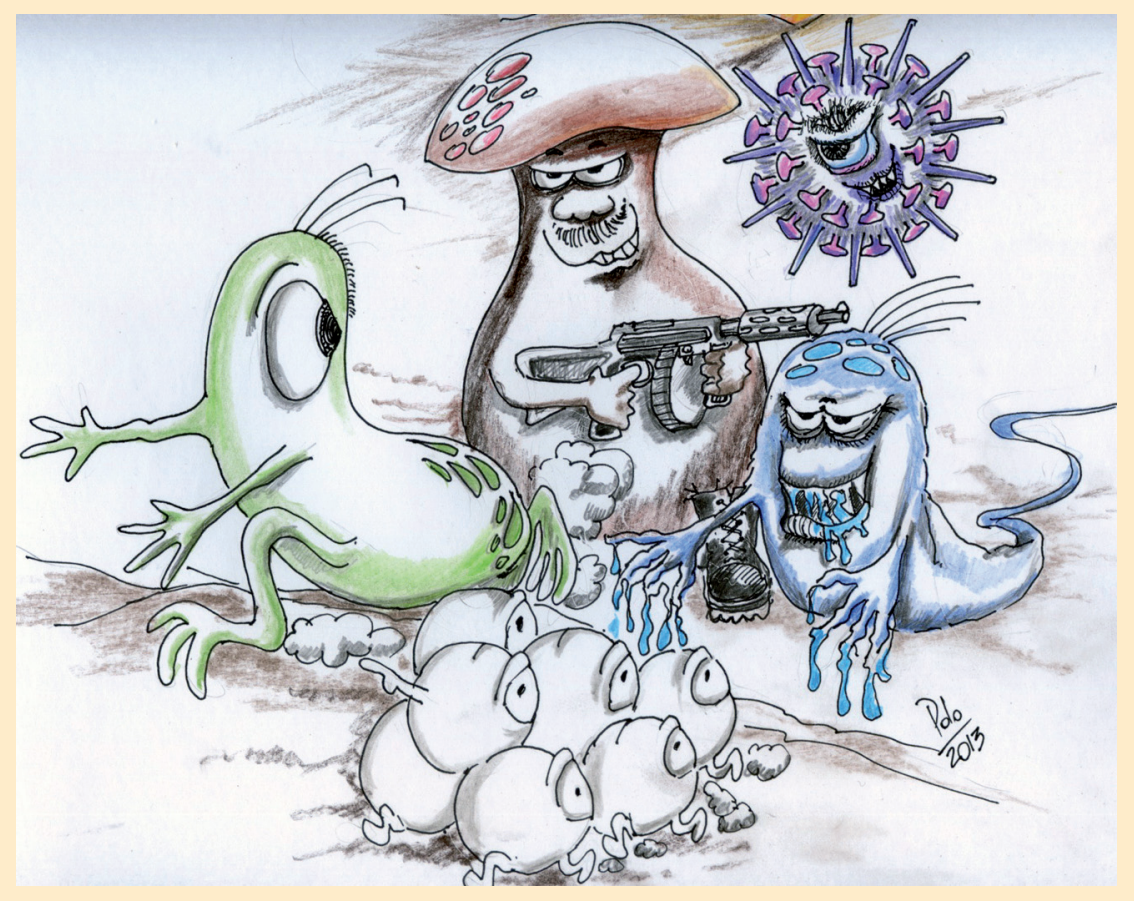

nologías... ${ }^{1}$. No estaba errado en su juicio el imaginario pontífice y, avergonzados, intentamos profetizar partiendo del pasado a través de la historia de los antibióticos, para encontrarnos muy pronto, al abordar las observaciones sobre el antagonismo que hicieran los bacteriólogos de fines del siglo XIX, con una profecía que pudiéramos haber hecho ya cumplida, en tanto que otras dos mantienen posibilidades. Así, fueron auténticos profetas Pasteur y Joubert al decir, en su comunicación a la Academia de Ciencias de Paris sobre septicemia y carbunco, donde mostraban la existencia de este antagonismo y señalaban el camino a seguir : Estos hechos quizá justifiquen las más grandes esperanzas para la terapéutica ${ }^{2}$. En cuanto a los profetas D'Herelle y Besredka, su crédito, nos parece, no está agotado.

\section{Bacterias que matan bacterias}

Entre 1889 y 1913 varios investigadores, empezando por Rudolf Emmerich y Oscar Loew, intentaron enfrentar infecciones sistémicas con la famosa piocianasa, el pigmento azul de Pseudomonas aeruginosa. En un comienzo hubo gran entusiasmo entre los médicos, pues era eficaz frente a los microrganismos de la difteria, fiebre tifoidea, carbunco y peste bubónica, pero, por desgracia, era muy tóxica al inyectarse por vía intravenosa en animales, por lo cual sólo servía en forma tópica, para el tratamiento de lesiones superficiales. En realidad, el principio activo en las experiencias realizadas con ésta y otras especies estaba constituido por las biocinas, antibióticos muy potentes pero con estrecho espectro de acción, destinados 
a inhibir a otras bacterias de la misma especie: piocinas en Pseudomonas aeruginosa y colicinas en Escherichia, por ejemplo.

Cuando vivía en la naturaleza, la Pseudomonas aeruginosa defendía su territorio contra sus congéneres secretando estas piocinas, proteínas en forma de bastoncillos, similares a la cola de los bacteriófagos, los virus miserables que parasitan bacterias. Las piocinas se unen a receptores específicos de otras cepas de la misma especie, destruyéndolas arteramente. Una de ellas, producida por Pseudomonas fluorescens, se ha hecho famosa gracias a un azar de la naturaleza, que le permite no sólo eliminar a otras cepas hermanas, sino también al Staphylococcus aureus: el antibiótico tópico conocido como mupirocina.

Cuando los primitivos bacteriólogos buscaban la piocianasa, capaz de matar al Bacillus anthracis y a otras especies bacterianas, así como de lisar al Vibrio comma, sin duda, el principio activo en sus filtrados libres de bacterias eran las piocinas, y como diferentes cepas producen diferentes variedades de éstas, a veces tenían éxito en sus experimentos y a veces no. En estos filtrados de piocianasa reconocían tres fracciones de la sustancia bactericida, una de las cuales era el pigmento azul. En 1889 Bouchard inyectó Bacillus pyocyaneus - que así llamaban entonces a la Pseudomonas aeruginosa- a un animal de laboratorio previamente infectado con Bacillus anthracis, y la infección se detuvo al punto ${ }^{3}$. Entusiasmados con este resultado, un cuarto de siglo después Fortineau y Fortineau intentaron seriamente tratar el carbunco en humanos con la famosa piocianasa, inyectando a un total de 50 enfermos con 10 a $20 \mathrm{ml}$ de un cultivo de $B$. pyocyaneus previamente esterilizado: la letalidad fue de $10 \%$, "un resultado no muy satisfactorio" 4,5 .

Resultados similares obtuvieron varios investigadores en diversas enfermedades humanas tratadas con "vacunas" de B. pyocyaneus, empleándose, por ejemplo, en limpiar distintas úlceras y senos paranasales e, incluso, directamente sobre la pseudomembranas diftéricas, pese a lo cual ya en 1929 eran "raramente empleadas"6. Con todo, puede decirse que el bacilo piociánico y su piocianasa dieron comienzo a la carrera armamentista contra las bacterias, que desembocó en el descubrimiento de los antibióticos. El término antibiótico, en todo caso, es muy posterior y, según una leyenda no confirmada, dataría de 1940, cuando Selman Waksman, el de la estreptomicina, lo propuso a su editor, pero ya antes Vuillemin había hablado de antibiote ${ }^{7}$.

En breve se vio que los hongos eran todavía más eficaces en los combates fratricidas, siendo capaces algunos de ellos de derrotar a varias especies bacterianas. Se atribuye a Schiller haber sido el primero en proponer la expresión de "antagonismo condicionado", gracias a investigaciones que realizara entre 1917 y 1924, terminando por formular una hipótesis que no dudamos en calificar de "caníbal".
Según Schiller, quien no era ciertamente el célebre dramaturgo, amigo de Goethe y autor de Guillermo Tell y otras joyas literarias, si se privaba de todo alimento a un cultivo de levaduras, que son hongos sin micelio, éstas podían alimentarse sólo de unas cuantas bacterias en agua destilada.

Este hoy ignorado genio continuó, como la mayoría de los autores de su tiempo, trabajando con bacterias del género Bacillus y ensayando, con relativo éxito, la acción in vitro e in vivo del entonces estimado inofensivo -para nosotros-Bacillus subtilis, un bacilo esporulado ambiental, muy frecuente en el aire de los laboratorios y famoso por contaminar los cultivos, sobre nada menos que el Mycobacterium tuberculosis ${ }^{8}$. Otras experiencias en este sentido, que culminarían con Waksman y Schatz obteniendo la estreptomicina a partir de un hongo Streptomyces, fueron las de Catani con el Bacterium termo, la de Klein erradicando de una cobaya el bacilo de Koch mediante la Pseudomonas aeruginosa, especie que Bouchard había utilizado para tratar el carbunco?.

De Schiller no hemos podido averiguar ni la inicial del nombre, y el único científico germánico con ese apellido que figura en nuestro diccionario Dorland's es Walter Schiller (1887-1960), quien no era alemán, sino austriaco, y vivía en EEUU; tampoco era bacteriólogo, sino patólogo, inventor de un test para diagnóstico precoz del cáncer a células escamosas ${ }^{10}$. Por su parte, Internet nos refiere masivamente al mencionado poeta y dramaturgo Friedrich Schiller, pero hemos rebuscado en sus obras y en su Guillermo Tell sólo encontramos antagonismo entre el héroe y el gobernador austriaco Gessler, es decir, entre suizos y austriacos, antagonismo que no se resuelve con el famoso acierto a la manzana, un tiro ganador, como dicen en los partidos de tenis: es, por el contrario, su inicio ${ }^{11}$.

Siguiendo con nuestra historia, no menos dramática, ya en el siglo XX y antes de los antibióticos, el antagonismo microbiano era un tópico importante y no faltaban los investigadores que se abocaban a él, siendo en nuestro medio muy destacada la actuación de Emiliano Armijo, médico con formación en Inglaterra, becado por el British Council, y en Italia, en el Instituto Superior de Sanidad, capacitado así para ser el impulsor de la instalación de una planta para fabricar penicilina en Chile. Estudioso del tema, nuestro compatriota, admirador de Dubos y siguiendo a Waksman, señalaba los cuatro grupos de antagonistas y las substancias obtenidas:

Grupo I. Algunos Gram negativos no esporulados pertenecientes al género Pseudomonas. Se incluyen aquí dos especies conocidas de antiguo, el piociánico y el fluorescens. Substancias extraídas del piociánico.

Grupo II. Algunos esporulados pertenecientes a los géneros Mycoides y Mesentericus. Gramicidina y tirotricina, obtenidas por purificación de la tirotricina, substancias obtenidas de esporulados Gram negativos de la tierra. 
Grupo III. Ciertos actinomyces. La actinomicina, obtenida y descrita por Waksman de una variedad de actinomyces.

Grupo IV. Ciertos hongos: la penicilina ${ }^{12}$ ( $\mathrm{iEl}$ triunfo había llegado!).

Cuando los investigadores se centraron en el grupo IV, los hongos, comenzaron a aparecer los antibióticos: de hecho, al momento de escribir Armijo, ya habían nacido.

\section{Virus que lisan bacterias}

También hubo quien pensó en utilizar los virus contra las bacterias, antagonismo en que nadie había reparado. Aunque los bacteriófagos, es decir, los virus que parasitan y destruyen las bacterias, fueron descubiertos por el inglés Frederik Twort (1877-1950), el principal impulsor de la idea de emplearlos en el tratamiento de enfermedades infecciosas fue el francés Félix D'Herelle, que hasta hace poco en varias biografías ${ }^{13,14}$ y otras referencias aparecía como canadiense. En un excelente artículo, Sonia Lozano nos cuenta la increíble vida aventurera de este investigador ${ }^{15}$.

Félix nace en Paris el 25 de abril de 1873, como Félix Haerens, hijo de Augustine Joseph Haerens; más tarde tomaría el apellido D'Herelle ${ }^{16}$. Estudia en un liceo de su ciudad y a los 18 años viaja a Inglaterra, paseo que le permite aprender inglés, lengua imprescindible ya en el mundo científico; de allí pasa a Alemania donde alcanza a estudiar apenas unos meses en la Universidad de Bonn, pues a los 20 años lo atrapa la Armada de Francia. No estaba el hombre dispuesto a la guerra, aunque luego la diera a las bacterias, de manera que deserta al año y se casa con Marie, bella hija del cónsul francés en Estambul, dando comienzo a su vida aventurera.

En 1897, con 24 años, lo encontramos en Québec, atendiendo una chocolatería con su hermano, comercio que no demora en ir a la quiebra: ni armas ni chocolates quería Félix. Así pues, en 1899 se alista en una expedición geológica en Labrador, en calidad de médico, lo cual nos deja perplejo: ¿dónde estudió medicina, si apenas estuvo unos meses en la Universidad de Bonn, luego se embarcó, desertó, se casó y fue a vender chocolates durante cuatro años en Québec? ¡Qué fácil era titularse de médico en esos tiempos aventureros y románticos! Clara prueba de que no era médico es el contrato que después de hacer de geólogo le hizo el gobierno de Québec para destilar jarabe y fabricar whisky, llevado, según el mismo cuenta en su autobiografía, por su admiración por Pasteur y sus trabajos en la fermentación por bacterias.

No contento con posar primero de médico y después de geólogo, luego se las da de químico, puesto que como tal firma en 1901 su artículo "De la formation du charbon par les végétaux" en el periódico "Le naturaliste canadien" "16. Pero...joh, sorpresa!.. ese mismo año lo vemos viajar a Guatemala, ahora como bacteriólogo. ¡Sólo tenía 28 años y ya era médico, especialista en bacteriología, chocolatero y geólogo!

Para justificar su zigzagueante carrera o, mejor, su insólito descaro, en su autobiografía diría que en 1890, cuando tenía 17 años y viajaba en el Royal Mail desde Brasil a Francia, había visto un brote de fiebre amarilla en el barco, sintiendo entonces nacer su vocación de microbiólogo: "Es probable que yo tenga, de nacimiento, la principal cualidad requerida para ser un buen cazador de microbios; la mayoría de los pasajeros estaban angustiados; yo preferi guardar la calma, pensaba que yo era invencible; es como un sentimiento de seguridad frente al peligro, que me viene de mi empedernido optimismo" "17.

En Guatemala, sin ninguna formación microbiológica y solamente por ser francés - ¡nuestro triste complejo frente al europeo!- es contratado no sólo como bacteriólogo del Hospital General del país, sino también como "profesor" de bacteriología, junto a su compatriota el químico René Guérin, que no es, por cierto, el de la vacuna BCG. Todo esto nos lleva a pensar que nuestro héroe aplicó el dicho echando a perder se aprende, practicándolo con todo desparpajo en nuestra América Latina de entonces, pues de Guatemala pasó a México y de ahí a Argentina, realizando las tareas más insólitas: fabricó whisky a partir del plátano, ayudó a controlar epidemias de fiebre amarilla, trabajó en el control biológico de plagas...

Sin embargo, talento tenía y éxito habrá logrado en varias de estas actividades, puesto que en 1911 da el gran salto y es contratado como asistente de investigación en el Instituto Pasteur de Paris, donde se une al profesor Elviava para iniciar en Rusia las investigaciones con bacteriófagos, virus que parasitan las bacterias, alcanzando así un lugar en la historia de la medicina.

D’Herelle nunca vio los bacteriófagos, limitándose a filtrar las deposiciones de los enfermos y a lisar, que significa destruir por completo, con este filtrado cultivos rebosantes de bacilos de Shiga. Luego aplicó su filtrado a los enfermos, estableciendo una serie de reglas y principios de administración, pero su tratamiento no fue convincente. Sin conocer los trabajos de Twort, creyó haber descubierto un germen invisible, publicando su hallazgo en 1917 en las Comptes Rendus de la Academia de Ciencias de París, bajo el título "Sobre un microbio invisible antagonista de los bacilos de la disentería", al cual -y ése fue su mérito- bautizó en 1918 como bacteriófago ${ }^{18}$.

Sin embargo, nadie hizo mucho caso ni vio claras aplicaciones para sus trabajos y, para mayor desgracia y oscurecimiento, años más tarde Jan Kapisek sí logró espectaculares resultados en el campo de concentración de Terezin, repleto de prisioneros aquejados de disentería 
que los alemanes habían dejado allí. Las pruebas de laboratorio sugerían, sin embargo, que el agente causal era una cepa atóxica de bacilo de Flexner y no un auténtico Shiga, "pero el curso de la enfermedad en esos detenidos, esposados, subalimentados y torturados era hipertóxico". Kapisek dio a cada enfermo $20 \mathrm{ml}$ tres veces al día, con té o café, luego de alcalinizarles el estómago; si vomitaban, se les administraba $150 \mathrm{ml}$ vía rectal, con una sonda $\mathrm{Ne}$ laton. De acuerdo a su gravedad, los enfermos mejoraron entre uno y tres días, cayendo la mortalidad del 34 al 5\%, en tanto que el $5 \%$ de recidivas mejoró con la vía rectal. En total, Kapisek trató a tres mil enfermos graves con 913 litros de bacteriófagos ${ }^{19}$.

\section{Los antivirus compiten por receptores titulares}

Otra forma más sutil de antagonismo microbiano fue el uso de "antivirus", extractos bacterianos presentes en un filtrado de cultivo que competían por los receptores titulares con las bacterias infectantes, terapia desarrollada por el ucraniano, más tarde nacionalizado francés, Alexander Mikhailovich Besredka (1870-1940), discípulo y colaborador del ruso Elia Metchnikoff en el Instituto Pasteur de París. Hombre modesto, Besredka escribió varios libros de inmunología, todos ellos en francés, en los cuales omite su nombre, figurando sólo como "A. Besredka", y siempre con la misma dedicatoria: "A la memoire vénerée de mon Maître Elie Metchnikoff”. Del más célebre de estos textos, Antivirusthérapie, hemos extractado los hechos fundamentales de su terapia ${ }^{20}$.

Besredka trabajó inicial -y luego preferentementecon estafilococos, estimándolos quizás un desafío por su dificultad para preparar con ellos vacunas tradicionales. $\mathrm{Al}$ respecto decía: Es uno de los raros virus sobre los cuales los procedimientos usuales de inmunización tienen poco de donde agarrarse: en el animal, la vacunación activa es dificil de realizar; en cuanto a la vacunación pasiva, ella puede ser considerada como inexistente. Aclaremos, de paso, que el investigador ucraniano llamaba virus a todos los agentes infecciosos, fuesen virus propiamente tales o bacterias.

Los antivirus eran un filtrado que contenía, presuntivamente, algunos constituyentes del estafilococo, provenientes de la pared celular, de la cápsula y algunos, quizás, del citoplasma mismo. Las bacterias se sembraban en caldo peptonado y se incubaban diez días a $37^{\circ} \mathrm{C}$, tras lo cual el cultivo se filtraba a través de tierra de infusorios y de bujías de porcelana, siendo luego estos filtrados resembrados con la misma cepa e incubados en iguales condiciones. Una nueva filtración arrojaba un líquido claro, con la apariencia de un caldo ordinario, que contenía la sustancia antagonista: el antivirus.
El antivirus ejercía su acción antagonista sobre el virus, no directamente, a la manera de una antitoxina o de un anticuerpo, sino indirectamente, haciendo a las células receptoras menos ávidas de virus. Podemos suponer, entonces, que había una competencia por los receptores en los tejidos entre los estafilococos infectantes y algunos de sus antígenos presentes en el antivirus. Partía Besredka de la base que cada especie bacteriana tenía una acción específica sobre grupos determinados de células; por lo tanto, era natural que esta especificidad fuera también propia de los "derivados inmediatos" de estas bacterias.

El antivirus se aplicaba localmente sobre el tejido infectado y rápidamente llevaba a la curación. Besredka y sus seguidores usaron esta terapia exitosamente en infecciones cutáneas, orales, oftálmicas, óticas, urológicas, ginecológicas, obstétricas y quirúrgicas, fabricando antivirus para diversas especies bacterianas: Staphylococcus aureus, Escherichia coli, Streptococcus pneumoniae, Streptococcus pyogenes, Vibrio cholerae, Pseudomonas aeruginosa, Salmonella Typhi, Salmonella Paratyphi B, Shigella dysenteriae, Bacillus prodigiosus (¿Serratia marscecens?) y varias más.

Besredka establece en sus textos las propiedades de esta terapia:

- Los antivirus no tienen acción bactericida.

- Paralizan o retardan el crecimiento de las bacterias infectantes compitiendo por los receptores celulares.

- El fenómeno se produce en ausencia de anticuerpos humorales.

- Su acción es local, selectiva y específica.

- Su inyección o administración oral o por cualquier vía no confiere inmunidad a los animales de experimentación.

- Tienen acción específica activando los fagocitos locales.

Con el advenimiento de los antibióticos la terapia de Besredka, muy controvertida y cuestionada, terminó por desaparecer. En la década de los ochenta, buscando cómo erradicar de las fosas nasales los agresivos fagotipos 80/81 de Staphylococcus aureus, se probó bloquear sus receptores implantando al paciente otros fagotipos más pacíficos: en su tumba, Besredka habrá sonreído. Otros motivos para sonreír tenía también, y muchos, este ruso nacionalizado francés, profesor del Instituto Pasteur, oficial médico en Verdun durante la primera guerra mundial, protector de la salud pública de los judíos... A riesgo de irritar a Celestino VI, es decir, a Giovanni Papini, como "archivadores de epitafios", queremos sintetizar su obra con el resumen del obituario que Nature publicara en 1940:

La reciente muerte del Profesor A. Besredka a la edad de setenta, priva a Francia de un miembro más del tristemente disminuido grupo de cientificos cuyos nombres están asociados al trabajo brillante y provocativo 
producido en los primeros dias del Instituto Pasteur. La mención del nombre de Besredka inmediatamente evoca la concepción de la inmunidad local opuesta a la inmunidad general o humoral; una concepción que ha levantado considerable controversia, provocando asi mucho y fructifero trabajo experimental sobre la naturaleza de la inflamación y la reacción del cuerpo a la infección. Ninguna memoria, sin embargo, estaría completa sin pagar tributo al trabajo pionero de Besredka en muchos campos de la bacteriología y de la inmunología.

Durante sus primeros tiempos en París fue asistente de Metchnikoff. Aplicó los métodos del maestro en un iluminativo estudio de la reacción de los fagocitos a exo y endotoxinas bacterianas y a la inyección de tóxicos minerales. Más tarde, Besredka hizo importantes contribuciones al desarrollo de inmunización específica contra la infección, notablemente en sus estudios sobre la estreptolisina y el uso de vacunas sensibilizadas. El shock anafiláctico, anormal y a veces desastrosa respuesta inmune a la inyección de proteína extraña, también reclamó su atención ${ }^{21}$.

\section{Resumen}

La historia de los antibióticos comienza con las primeras observaciones de Pasteur y Joubert sobre el antagonismo entre bacterias, realizadas a fines del siglo XIX. Tres tipos de antagonismo fueron objeto de estudio: bacterias que mataban a otras bacterias, virus capaces de lisar bacterias y bloqueo de receptores celulares del huésped por filtrados bacterianos. En el primer tipo de antagonismo, los mejores ejemplos fueron la actividad de la piocianasa producida por Pseudomonas aeruginosa y la acción de Bacillus subtilis sobre Mycobacterium tuberculosis; en el segundo descuella el francés D'Herelle como pionero al emplear bacteriófagos contra Shigella dysenteriae, en tanto que el ucraniano-francés Besredka encabeza el tercer tipo con su "antivirusthérapie" en Syaphylococcus aureus. Con el tiempo, la primera línea triunfaría, con una ligera modificación, al enfrentar hongos contra bacterias.

\section{Referencias bibliográficas}

1.- Papini G. Lettere agli uomini di Papa Celestino VI.

Firenze 1946. Versión española de Carlo Povo en: Papini, G. Obras completas. IV: 923-1059. Aguilar, S.A. de Ediciones, Madrid 1960.
2.- Pasteur L, Joubert J F. Antagonisme microbienne. Comp Rend Acad Sci Paris 1877; 85: 101.

3.- Bouchard C. Bacillus pyocyaneus. Com Rend Acad Sci Paris 1889; 108: 713.

4.- Fortinau L, Fortineau C. Com Rend Acad Sci Paris 1914; 158: 1035.

5.- $\quad$ Eurich F W, Hewlett R T. Bacillus anthracis, En: Medical Research Council. A system of bacteriology in relation to medicine. His Majesty's Stationery Office, London 1929; V: 471.

6.- Wilson W J. The Fluorescens-Pyocyaneus Group. En: Medical Research Council. A system of bacteriology in relation to medicine. His Majesty's Stationery Office, London 1929; IV: 325- 37.

7.- González Jáuregui M. Medicamentos antituberculosos. Real Academia de Farmacia, Instituto de España, Discurso leído en la Solemne Sesión Inaugural del Curso 1948-49, Madrid 1949.

8.- Schiller. Bacillus subtilis. Zentralblatt für Bakt 1925; 96: 54; 1927; 103: 304

9.- Waksman S. Microbial antagonisms and antibiotic substances. New York, 1945.

10.- Schiller's test. Dorland's Illustrated Medical Dictionary. Edition 28. W.B.Saunders Co., Phi 1994; pp. 1490, 1684.

11.- Schiller F. Guillermo Tell. S.A. de Promoción y Ediciones. Madrid 1970.

12.- Armijo E. Notas sobre antagonismo microbiano. Bol Inst Bacteriol Chile 1943; II (3): 97-102.

13.- Ackerman, H. Félix d'Herelle, découvrer des bactériophages. Selec Méd Sci 1988; 8: 1-6.

14.- Summers W. Félix d'Herelle and the origins of molecular biology. University Press, Yale 1999.

15.- Lozano S. Félix d’Hérelle en México (1904-1911). Bitácora-e Revista Electrónica Latinoamericana de Estudios Sociales, Históricos y Culturales de la Ciencia y la Tecnología, 2006, No.13:

16.- Dublanchet A. The epic of phage therapy. Can J Infect Dis Med Microbiol 2007; 18 (1): 15-8.

17.- D'Herelle F. Les périgrinations d'un microbiologiste. Masson et Cie, Paris 1921.

18.- D'Herelle, F. Sur un microbe invisible antagoniste des bacilles dysentériques. Comp Rend Acad Sci Paris 1917; 165: 373-5.

19.- Kapisek J. Contribution à l'emploi du bacteriophage dans le traitement de la dysenterie bacillaire. Presse Méd 1947 (Juin 21): 422-3.

20.- Besredka, A. Antivirusthérapie. Applications a l'ophtalmologie, l'oto-rhino-laryngologie, la stomatologie, l'entérologie, l'urologie, la gynecologie et obstétrique, la dermatologie, la chirurgie, la médecine vétérimaire, la sérothérapie locale. Paris, Masson \& Cie, éditeurs. Libraires de l'Academie de Médecine, 1930.

21.- Obituary. Prof. Alexandre Besredka. Nature 1940 (20 April); 145: 617-8. 